\title{
Arylowe izoprenoidy jako wyznaczniki stref anoksycznych kolumny wody
}

\begin{abstract}
Niniejsza praca wskazuje na użyteczność arylowych izoprenoidów jako wskaźników do uszczegółowienia występowania stref fotycznych w środowisku sedymentacji osadów. Dokonano przeglądu 50 próbek bituminów wyizolowanych przez ekstrakcję próbek skał, zróżnicowanych stratygraficznie i litologicznie, pod względem występowania i dystrybucji arylowych izoprenoidów. W kilkunastu próbkach, w których stwierdzono obecność tych związków, została wykonana analiza korelacyjna z uwzględnieniem składu molekularnego arylowych izoprenoidów, które są użyteczne do oceny warunków paleośrodowiskowych. Na podstawie rozpoznania literaturowego wybrano wskaźniki geochemiczne, które posłużyły do określania stref anoksycznych. Arylowe izoprenoidy są pochodnymi izorenieratenu, czyli pigmentu, który występuje m.in. w zielonych bakteriach siarkowych (Chlorobiaceae). Dla tego typu bakterii niezbędnymi do życia czynnikami są światło i siarkowodór $\left(\mathrm{H}_{2} \mathrm{~S}\right)$. Z tego względu izorenieraten, jak również związki pochodne, m.in. arylowe izoprenoidy (takie jak trimetyloarylowe izoprenoidy) oraz diarylowe izoprenoidy, są bardzo dobrymi wskaźnikami warunków anoksycznych (beztlenowych) w strefie fotycznej. Pozwalają one także ocenić czas trwania fotycznej strefy anoksycznej (PZA). Wykorzystanie arylowych izoprenoidów w połączeniu z interpretacją powszechnie stosowanego wskaźnika Pr/Ph pozwala na uściślenie warunków środowiskowych.
\end{abstract}

Słowa kluczowe: arylowe izoprenoidy, fotyczna strefa anoksyczna, środowisko sedymentacji.

\section{Aryl isoprenoids as indicators of the anoxic zones of the water column}

The aim of this work is to show the method of identification of compounds from the aryl isoprenoids group, for elaborating the information about photic zones during sedimentation. Several dozen bitumen extracts (from different geological settings) were used for this purpose. The presence of aryl isoprenoids compounds was proven in a dozen of 50 tested samples. Correlation analysis with a composition of isoprenoid compounds which are widely used for paleoenvironmental condition assessment, was conducted for these samples. After literature studies, the authors attempted to select geochemical markers which could be useful for anoxic zones determination. Aryl isoprenoids are derivatives of isorenieratene - a pigment which occurs in green sulfur bacteria (Chlorobiaceae). For these kinds of bacteria, the factors required to control their lives, are light and hydrogen sulfide content. Because of this fact the isorenieratene and derivative compounds like aryl isoprenoids (trimethylaryl isoprenoids) and diaryl isoprenoids are very good indicators of anoxic (anaerobic) condition in a photic zone. They are also useful in the estimation of photic zone anoxia (PZA) duration in time. The use of aryl isoprenoids combined with the interpretation of a commonly used $\mathrm{Pr} / \mathrm{Ph}$ indicator allows to specify environmental conditions.

Key words: aryl isoprenoids, photic zone anoxia, depositional environment.

\section{Wstęp}

Strefa fotyczna to powierzchniowa warstwa kolumny wodnej, w której produkcja biogennej materii organicznej przeważa nad rozkładem obumarłej materii organicznej. Dolna granica tej strefy to głębokość, do jakiej dociera $1 \%$ promieniowania fotosyntetycznie czynnego.
Częstym zjawiskiem w wodnym środowisku sedymentacji w przeszłości geologicznej było występowanie warunków beztlenowych w zakresie od dna zbiornika wodnego do wód strefy fotycznej. Okresy istnienia fotycznej strefy anoksycznej (PZA) mogą być rozpoznane dzięki obecności lipidów 
produkowanych wyłącznie przez Chlorobiaceae. Bakterie te żyją na poziomie tlenowo-beztlenowej warstwy granicznej lub poniżej tej strefy (rysunek 1). Chlorobiaceae mają zdolność w warunkach beztlenowych do fotosyntezy, która zachodzi w wodach nasyconych siarkowodorem przy dostępie światła widzialnego $[1,2,5]$.

Silniejsze warunki anoksyczne i euksyniczne (większe zawartości $\mathrm{H}_{2} \mathrm{~S}$ ) sprzyjają zachowaniu materii organicznej. Pokrywanie się tych stref (anoksycznej i euksynicznej) jest czynnikiem korzystnym dla rozwoju zielonych i purpurowych bakterii siarkowych. Bakterie te używają aromatycznych karotenoidów jako barwników absorbujących światło do procesu fotosyntezy. Przykładowe struktury karotenoidów (m.in.: izorenieraten, karoten) przedstawiono na rysunku $2[11,12]$.

Arylowe izoprenoidy pochodzą z zielonych, purpurowych i brązowych bakterii siarkowych Chlorobiaceae. Arylowe izoprenoidy o strukturze monoaromatycznej i metylowych podstawnikach w położeniach 2, 3, $6 \mathrm{w}$ pierścieniu benzenowym pochodzą od izorenieratenu. Związki te mogą uszczegółowić opis basenu sedymentacyjnego poprzez wyznaczenie głębokości fotycznej strefy anoksycznej. Koncentracja arylowych izoprenoidów odzwierciedla produktywność chlorobakterii. Produktywność ta zależna jest od stopnia i czasu współwystępowania stref anoksycznej i fotycznej lub też od dostępności niezbędnych substancji odżywczych [11, 12].

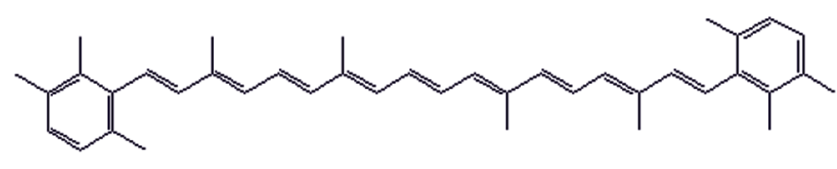

Izorenieraten

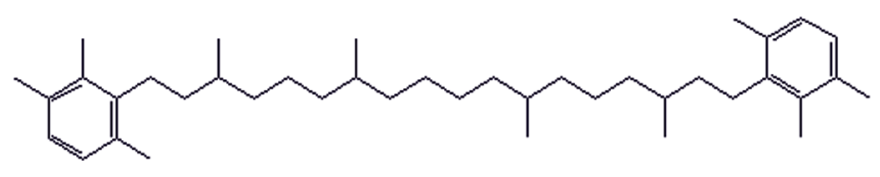

Izorenieratan

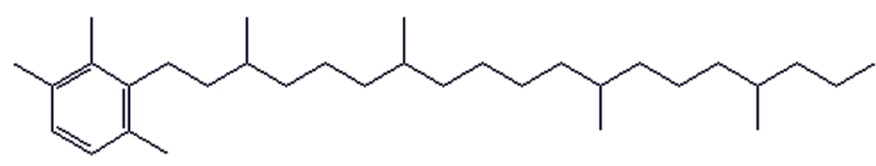

Arylowy izoprenoid

Rys. 2. Wzory strukturalne izorenieratenu i innych karotenoidowych pochodnych, w tym arylowych izoprenoidów

Występowanie homologów $\mathrm{C}_{13}-\mathrm{C}_{31}$ arylowych izoprenoidów jest wskazaniem obecności fotycznej strefy anoksycznej (PZA).
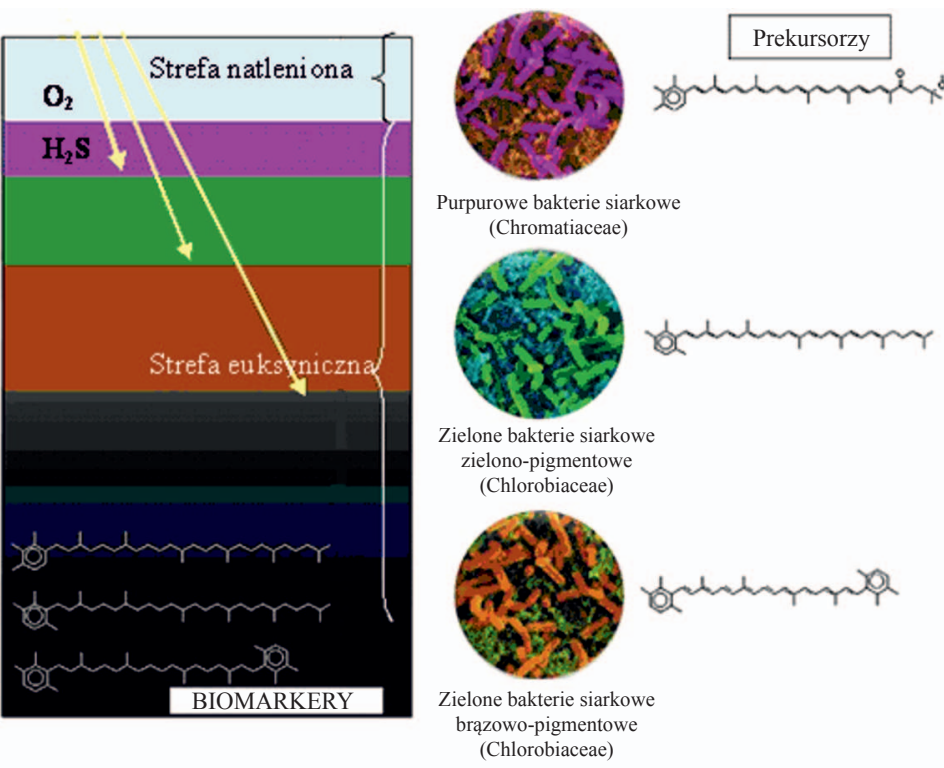

Rys. 1. Profil środowiska sedymentacji pokazujący interwały, w których występują zielone i purpurowe bakterie siarkowe. Modyfikacja według [12]

Najczęściej występują homologi krótkołańcuchowe $\left(\mathrm{C}_{13}-\mathrm{C}_{17}\right)$ $\mathrm{i}$ średniołańcuchowe $\left(\mathrm{C}_{18}-\mathrm{C}_{22}\right)$. Rola arylowych izoprenoidów jest dość istotna w określeniu zmian poziomu wód morskich i interpretacji cech sedymentologicznych i paleontologicznych w sekwencjach stratygraficznych. W wielu doniesieniach literaturowych $[4,7,9,11-15]$ można znaleźć potwierdzenie znaczenia tych związków w określaniu warunków sedymentologicznych.

L. Schwark i A. Frimmel w pracy [11] opisali wyniki badań arylowych izoprenoidów używanych do tworzenia modeli depozycyjnych. W swoich badaniach autorzy wykorzystali próbki pobierane w laminach o miąższości $2 \div 8 \mathrm{~mm}$. Laminy były tak cienkie, aby zminimalizować efekt zakresu czasowego. Osady, które poddano analizie, odznaczały się zawartością ekstrahowalnej substancji organicznej (ESO) w zakresie od 100 ppm do 13500 ppm. Warstwy węglanowe wykazywały niską zawartość ESO. Pod względem ilości substancji organicznej (ESO znormalizowano względem TOC) badane osady były bardzo podobne, z wyjątkiem dwóch warstw ze strefy reprezentowanej przez mułowce i czarne łupki.

Frakcja aromatyczna składała się głównie z benzenu, naftalenu, fenantrenu oraz dibenzotiofenu i ich metylowych pochodnych. Ponadto stwierdzono obecność tetrahydroretenu, mono- i triaromatycznych steroidów, aromatycznych sekohopanów oraz benzohopanów. Skład biomarkerów wskazywał na morskie pochodzenie materii organicznej i tlenowe środowisko sedymentacji (wartości wskaźnika $\mathrm{Pr} / \mathrm{Ph}>1$ ). Aby uzyskać więcej szczegółów, przebadano także biomarkery z grupy arylowych izoprenoidów, które występowały w tych osadach w zmiennych ilościach od 145 ppm do 2091 ppm. 
Wśród arylowych izoprenoidów obecne były homologi z zakresu $\mathrm{C}_{12}-\mathrm{C}_{22}$. Na podstawie dystrybucji tych związków oraz Pr i Ph, obliczonych wskaźników $\mathrm{Pr} / \mathrm{Ph}$, AIR (wskaźnik oparty na arylowych izoprenoidach $\mathrm{C}_{13-17} / \mathrm{C}_{18-22}$ ), a także koncentracji arylowych izoprenoidów [ppm] sporządzono diagramy dla interpretacji stref depozycyjnych [11]. Ponadto stwierdzono, że wzrost wskaźnika AIR następuje wraz ze zmniejszaniem się zawartości arylowych izoprenoidów. Wysokie wartości tego wskaźnika dają informację o epizodycznym występowaniu anoksycznej strefy fotycznej (PZA), niska wartość może natomiast odzwierciedlać długi czas trwania anoksycznej strefy fotycznej. Dystrybucja arylowych izoprenoidów w jednym profilu litologiczno-stratygraficznym może być bardzo zróżnicowana i czuła na zmiany fotyczne i zmienność poziomu wód. Ważne dla celów interpretacyjnych jest określenie relatywnej zawartości niskocząsteczkowych arylowych izoprenoidów w stosunku do tych o wyższej masie cząsteczkowej. Odnotowano szczególnie niskie stężenie arylowych izoprenoidów w mułowcach. Gwałtowny ich wzrost istnieje tam, gdzie są rozpoznane serie czarnych lupków. Stąd zawartość arylowych izoprenoidów w profilu może znacznie ułatwić ocenę występowania warstw łupkowych (np. shale gas lub shale oil). Jest to spójne z obecnością stref fotycznych. Dodatkowo wskazuje to na występowanie Chlorobiaceae, co oznacza, że są one biologicznym źródłem tych związków [11].

\section{Metodyka badań}

\section{Ekstrakcja bituminów (ESO)}

Ekstrakcję skał prowadzono w aparatach Soxhleta mieszaniną dichlorometan-metanol w stosunku objętościowym 93:7. 100 gramów próbki umieszczano w tulejach o średnicy $32 \mathrm{~mm}$ i wysokości $120 \mathrm{~mm}$. Ekstrakcję prowadzono przez 24 godziny. Otrzymany roztwór bituminów zatężano, odparowując nadmiar rozpuszczalnika, i przenoszono ilościowo do zważonego naczynka. Siarkę elementarną usuwano poprzez dodanie do roztworu bituminów aktywowanej granulowanej miedzi i pozostawienie go na kilka godzin, aż do całkowitego związania. Następnie roztwór przesączano przez sączek do nowego naczynka, odparowując rozpuszczalnik jak uprzednio.

\section{Rozdzial grupowy (SARA)}

Rozdział grupowy ekstraktu bitumicznego przeprowadzono w kolumnach chromatografii cieczowej. Węglowodory nasycone nie są sorbowane przez kolumnę i opuszczają ją z n-heksanem. Frakcję tę eluowano do zważonego uprzednio naczynka, zadając na kolumnę około $20 \mathrm{ml}$ n-heksanu, porcjami po około $4 \mathrm{ml}$. Po wymyciu węglowodorów nasyconych eluowano frakcję węglowodorów aromatycznych do innego oznaczonego i zważonego naczynka, używając około $15 \mathrm{ml}$ mieszaniny heksan-toluen w stosunku objętościowym 1:3. Proces prowadzono aż do zaniku luminescencji kolumny przy naświetlaniu promieniami UV. Pozostałe na kolumnie żywice eluowano do osobnego, zważonego naczynka za pomocą $15 \mathrm{ml}$ mieszaniny toluen-metanol w stosunku objętościowym 1:1, do której w końcowej fazie elucji dodano około $10 \mathrm{ml}$ dichlorometanu.

\section{Analiza GC/MS frakcji aromatycznej i nasyconej}

Analizę specyficznych biomarkerów frakcji aromatycznej oraz nasyconej przeprowadzano techniką chromatografii gazowej (GC) sprzężonej ze spektrometrią masową (MS), wykorzystując pułapkę jonową POLARIS Q wyposażoną w kolumnę RTX-5 MS (30 m × 0,25 mm, grubość filmu -0,25 $\mu \mathrm{m})$ i hel jako gaz nośny.

Stosowano poniższy program temperaturowy:

- temperatura początkowa $-60^{\circ} \mathrm{C}$ (izoterma $-1 \mathrm{~min}$ ),

- narost temperatury $4^{\circ} \mathrm{C} / \mathrm{min}$ do $310^{\circ} \mathrm{C}$,

- izoterma w temperaturze $310^{\circ} \mathrm{C}$ przez $15 \mathrm{~min}$.

Każdorazowo dozowano $1 \mu$ l próbki rozpuszczonej w n-heksanie.

Spektrogramy masowe frakcji aromatycznej i nasyconej analizowanych próbek otrzymane w trybie pełnego skanowania (TIC) oraz w trybie wybranych jonów fragmentacyjnych (SIM) poddawano obróbce komputerowej, wybierając do identyfikacji spektrogramy masowe konkretnych klas biomarkerów $(\mathrm{m} / \mathrm{z}=120, \mathrm{~m} / \mathrm{z}=133, \mathrm{~m} / \mathrm{z}=134)$. W interpretacji geochemicznej węglowodorów frakcji aromatycznej i nasyconej korzystano ze wskaźników opartych na łańcuchowych izoprenoidach i arylowych izoprenoidach.

\section{Identyfikacja wybranych arylowych izoprenoidów}

Do badań arylowych izoprenoidów wybrano próbki ekstraktów bituminów ze skał, które pochodziły z różnych rejonów geologicznych (między innymi: Karpaty, Niż Polski, basen bałtycki) i z różnych poziomów stratygraficznych (między innymi: dolomit główny, menility oligoceńskie, dolny paleozoik). Na kilkadziesiąt próbek sprawdzanych pod kątem występowania arylowych izoprenoidów w około $25 \div 30$ stwierdzono ich obecność. Na chromatogramach (rysunki 3 i 4) przedstawiono trimetyloarylowe izoprenoidy $(\mathrm{m} / \mathrm{z}=133, \mathrm{~m} / \mathrm{z}=134)$ oraz dimetyloarylowe izoprenoidy 
$(\mathrm{m} / \mathrm{z}=120)$ w próbkach karpackich oraz bałtyckich. Badając próbki, uwagę skupiono głównie na trimetyloarylowych izoprenoidach [3, 6, 10, 16], dla których wyznaczono wskaźniki AIR. Najczęstszym przypadkiem wśród badanych próbek była obecność trimetyloarylowych izoprenoidów w ograniczonym zakresie homologów. Zazwyczaj wyższe homologi arylowych izoprenoidów (powyżej $\mathrm{C}_{20}$ ), jak również diarylowe izoprenoidy (izorenieratan) występowały w znikomych ilościach lub nie stwierdzono ich obecności. Z tego względu niewielka liczba próbek okazała się przydatna do obliczania wskaźników AIR (aryl isoprenoid ratio) [11]. Były to próbki reprezentujące dolomit główny oraz menility oligoceńskie. W próbkach z dolomitu głównego (skały węglanowe) dzięki występowaniu trimetyloarylowych izoprenoidów w szerszym zakresie niż w próbkach z utworów fliszowych Karpat obliczono wskaźnik AIR. W próbkach tych obecne są struktury trimetyloarylowych izoprenoidów z podstawnikami metylowymi przy atomach węgla 2, 3, 6 na pierścieniu aromatycznym [6]. Sa to struktury monoaromatyczne w zakresie od $\mathrm{C}_{10}$ do nawet $\mathrm{C}_{31}$. W próbkach tych wartość wskaźnika $\mathrm{Pr} / \mathrm{Ph}$ wynosi poniżej 1 (waha się pomiędzy 0,45 a 0,67), co wskazuje na redukcyjne środowisko sedymentacji. Stwierdzono, że występujące w nich arylowe izoprenoidy charakteryzują się większą zawartością homologów w zakresie $\mathrm{C}_{18}-\mathrm{C}_{22}$ relatywnie do zawartości odpowiedników krótkołańcuchowych $\left(\mathrm{C}_{13}-\mathrm{C}_{17}\right)$, poza próbką O-2, co odzwierciedlają wartości wskaźnika AIR (tablica 1).

Próbki z dolomitu głównego okazały się mało przydatne do korelacji AIR ze wskaźnikiem $\mathrm{Pr} / \mathrm{Ph}$ według wykresu przedstawionego na rysunku 6 [11]. Z uwagi na niskie wartości stosunku $\mathrm{Pr} / \mathrm{Ph}$ poniżej 1 nie uwzględniono tych próbek na wykresie obrazującym zależność Pr/Ph do AIR (rysunek 6).

Próbki reprezentujące menility oligoceńskie (jednostka dukielska) ze względu na występowanie trimetyloarylowych izoprenoidów (co najmniej w zakresie niezbędnym do obliczenia wskaźnika AIR), jak również na przewagę Pr nad Ph były interpretowane w najszerszym zakresie. Przy interpretacji autorzy niniejszej pracy wykorzystali też swoją wiedzę dotyczącą innych grup biomarkerów znajdujących się w tych próbkach i charakteryzujących ich cechy genetyczne. Tych dodatkowych wyników nie załączono w niniejszej pracy. Natomiast zostały zamieszczone informacje uzyskane $\mathrm{z}$ ustnej konsultacji z dr Piotrem Dziadzio z INiG - PIB.

Próbka M-1 (rysunek 4) pochodzi ze stropowej części piaskowców z Mszanki. Dominującym związkiem pośród frakcji nasyconej jest pristan. Bardzo wysoka wartość wskaźnika $\mathrm{Pr} / \mathrm{Ph}$ (tablica 2) świadczy o środowisku tlenowym podczas depozycji osadów (deponowane są głównie roślinne utwory lądowe). Pristan w takim środowisku powstaje na drodze przemian chemicznych poprzez hydrolizę chlorofilu $\mathrm{z}$ uwolnieniem się fitolu, dalej jego przekształcenie do kwa-
Tablica 1. Wskaźniki obliczone na podstawie izoprenoidów i arylowych izoprenoidów dla próbek z dolomitu głównego

\begin{tabular}{|c|c|c|c|}
\hline Próbka & $\begin{array}{c}\text { Głębokość } \\
{[\mathrm{m}]}\end{array}$ & $\operatorname{Pr} / \mathrm{Ph}$ & AIR \\
\hline O-1 & 2816,95 & 0,51 & 0,46 \\
\hline O-2 & 2817,50 & 0,45 & 1,13 \\
\hline O-3 & 2818,70 & 0,67 & 0,23 \\
\hline O-4 & 2819,60 & 0,45 & 0,46 \\
\hline
\end{tabular}

$\mathrm{Pr} / \mathrm{Ph}-\operatorname{pristan} / \mathrm{fitan}$

AIR $-\mathrm{C}_{13-17} / \mathrm{C}_{18-22}$

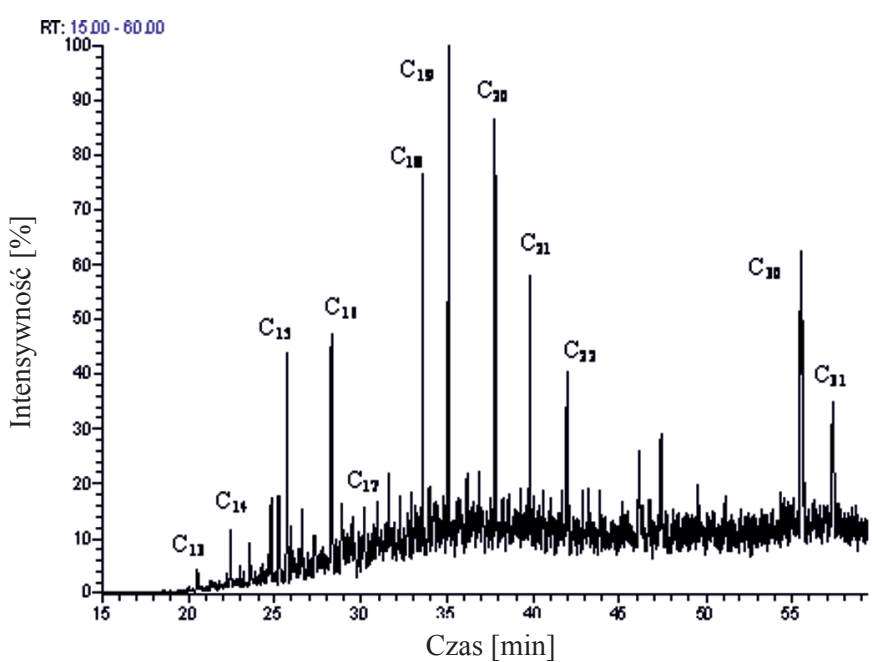

Rys. 3. Skład arylowych izoprenoidów w próbce O-1: trimetyloarylowe izoprenoidy $(\mathrm{m} / \mathrm{z}=133,134)$

su fitanowego i kolejno dekarboksylację w warunkach tlenowych na wczesnym etapie diagenezy. Dodatkowo fakt ten znajduje potwierdzenie w relatywnie wysokiej zawartości oleananu pochodzącego z roślin okrytonasiennych. Obecne diasterany pozwalają wnioskować o udziale materiału ilastego w osadzie, jak i zaawansowaniu procesów diagenetycznych.

Pośród monoaromatycznych struktur trimetyloarylowych izoprenoidów zdecydowanie przeważają homologi z krótkimi łańcuchami $\left(\mathrm{C}_{13}-\mathrm{C}_{17}\right)$ nad homologami średniołańcuchowymi $\left(\mathrm{C}_{18}-\mathrm{C}_{22}\right)$, przy braku homologów o wyższych masach molowych. Przewaga homologów o niższej liczbie atomów węgla w cząsteczce może wskazywać na intensywny przebieg aerobowych procesów degradacji arylowych izoprenoidów, przerywających występowanie epizodycznych okresów warunków beztlenowych.

Próbka M-2 pochodzi z serii menilitowo-rogowcowej dolnej (strefa przeddukielska) i charakteryzuje się wysokim udziałem ekstrahowalnej substancji organicznej, co świadczy o rozpoczęciu procesów generacyjnych. W składzie węglowodorów frakcji nasyconej dominują biomarkery, a wśród n-alkanów dominuje n- $\mathrm{C}_{21}$. $\mathrm{O}$ wyższej dojrzałości świadczy także mniejsza relatywna koncentracja izoprenoidów łańcuchowych nad odpowiednimi n-alkanami niż w próbce M-1. 
Na szczególną uwagę zasługuje brak 28,30-bisnorhopanu (BNH) oraz występowanie tricyklicznych terpenów w niskich koncentracjach, a także tetracyklicznego terpenu $\mathrm{T}_{24}$. Obecność $\mathrm{T}_{24}$ wskazuje na udział terygenicznej materii organicznej w osadach. Pośród arylowych izoprenoidów (monoaromatycznych) przeważają homologi o średniej liczbie atomów węgla w cząsteczce $\left(\mathrm{C}_{18}-\mathrm{C}_{22}\right)$ nad homologami krótkołańcuchowymi $\left(\mathrm{C}_{13}-\mathrm{C}_{17}\right)$. W próbce tej stwierdzono również obecność $\mathrm{C}_{33}$ diarylowego izoprenoidu, co wyróżnia ją na tle innych próbek menilitowych. Wskaźniki oparte na izoprenoidach łańcuchowych i arylowych świadczą o długotrwałych okresach występowania fotycznej strefy anoksycznej (rysunek 6).

Próbkę M-3 pobrano znad cienkiej warstwy rogowców, której cechy genetyczne świadczą o subtlenowym środowisku, gdzie osadzała się substancja morsko-lądowa. Wskaźniki oparte na izoprenoidach łańcuchowych i arylowych informują o tym, że w środowisku tym występowała długotrwała fotyczna strefa anoksyczna.

Próbka M-4, pobrana poniżej cienkiej warstwy rogowców, charakteryzuje się obecnością oleananu, świadczącego o pochodzeniu z materiału lądowego, i jednocześnie obecnością $\mathrm{BNH}$, wskazującego na działalność bakterii podczas depozycji osadów morsko-lądowych w środowisku słabo natlenionym. Uwzględniając informację opartą na wskaźnikach izoprenoidów łańcuchowych i arylowych, w środowisku tym panowała długotrwała fotyczna strefa anoksyczna.

Próbka M-5 reprezentuje osady z obrębu dolnej serii menilitowej - strop piaskowców z Mszanki i wykazuje zróżnicowanie w składzie arylowych izoprenoidów (rysunek 5). Skład steranów sugeruje na jednakowy udział substancji morskiej i lądowej w depozycji osadów. Wskaźniki oparte na izoprenoidach łańcuchowych i arylowych świadczą o krótkotrwałej (epizodycznej) fotycznej strefie anoksycznej.

Próbka M-6 pochodzi z obrębu margli podcergowskich. Środowisko sedymentacji wykazuje cechy subtlenowe $(\mathrm{Pr} / \mathrm{Ph}=1,19) . \mathrm{W}$ próbce tej występuje wysoka zawartość bisnorhopanu (BNH) oraz $\mathrm{C}_{29}$ norhopanu, co wskazuje na działalność bakterii podczas sedymentacji osadów [8]. Mała ilość substancji ilastej, wysoki udział substancji organicznej o charakterze algowo-glonowym i wysoki udział działalności bakteryjnej mogą skłaniać do wnioskowania o płytkowodnych, spokojnych warunkach sedymentacji, jakie spotyka się w obszarach jeziornych lub zastoiskowych, np. na równi deltowej. Można zatem wnioskować o ewaporacyjnych warunkach w basenie i krystalizacji siarczanów, które w wyniku bakteryjnej aktywności ulegają redukcji, co prowadzi do powstania siarki elementarnej.

W próbce M-7 (spąg piaskowców cergowskich z obrębu margli podcergowskich) występuje względnie duża ilość norhopanów, co może świadczyć o istnieniu węglowodorów na powierzchni sedymentacyjnej lub o intensywnym przetwarzaniu materii organicznej przez mikroorganizmy. Wskaźniki oparte na izoprenoidach łańcuchowych i arylowych informują o krótkotrwałej (epizodycznej) fotycznej strefie anoksycznej.

Tablica 2. Wskaźniki obliczone na podstawie izoprenoidów łańcuchowych i arylowych dla warstw menilitowych

\begin{tabular}{|c|c|c|}
\hline Próbka & Pr/Ph & AIR \\
\hline M-1 & 3,84 & 6,24 \\
\hline M-2 & 1,42 & 0,84 \\
\hline M-3 & 1,08 & 0,25 \\
\hline M-4 & 1,20 & 0,57 \\
\hline M-5 & 1,27 & 2,11 \\
\hline M-6 & 1,19 & 4,20 \\
\hline M-7 & 1,20 & 2,73 \\
\hline M-8 & 1,29 & 0,64 \\
\hline
\end{tabular}

$\mathrm{Pr} / \mathrm{Ph}-\operatorname{pristan} /$ fitan

AIR $-\mathrm{C}_{13-17} / \mathrm{C}_{18-22}$

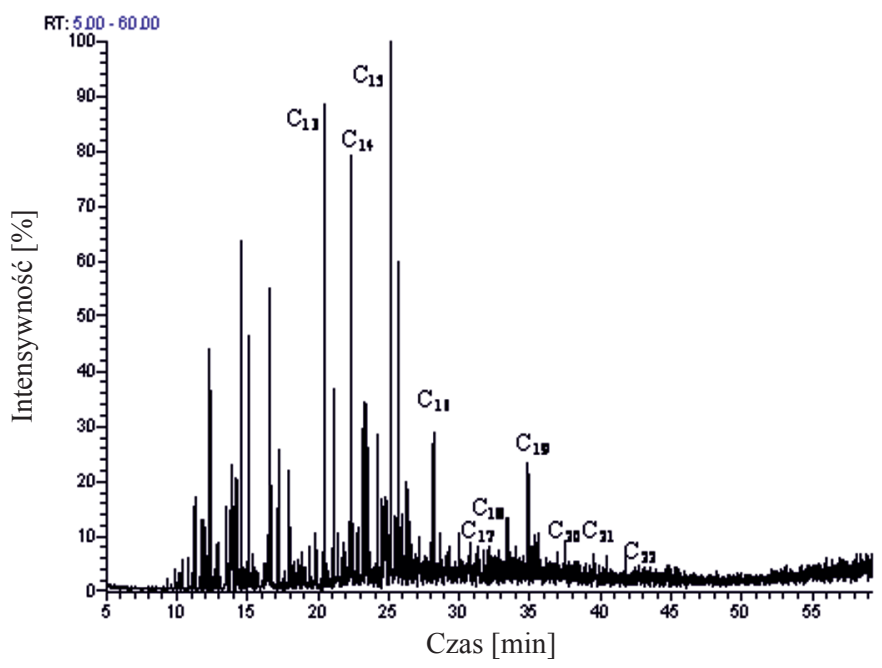

Rys. 4. Skład arylowych izoprenoidów w próbce M-1: trimetyloarylowe izoprenoidy $(\mathrm{m} / \mathrm{z}=133,134)$

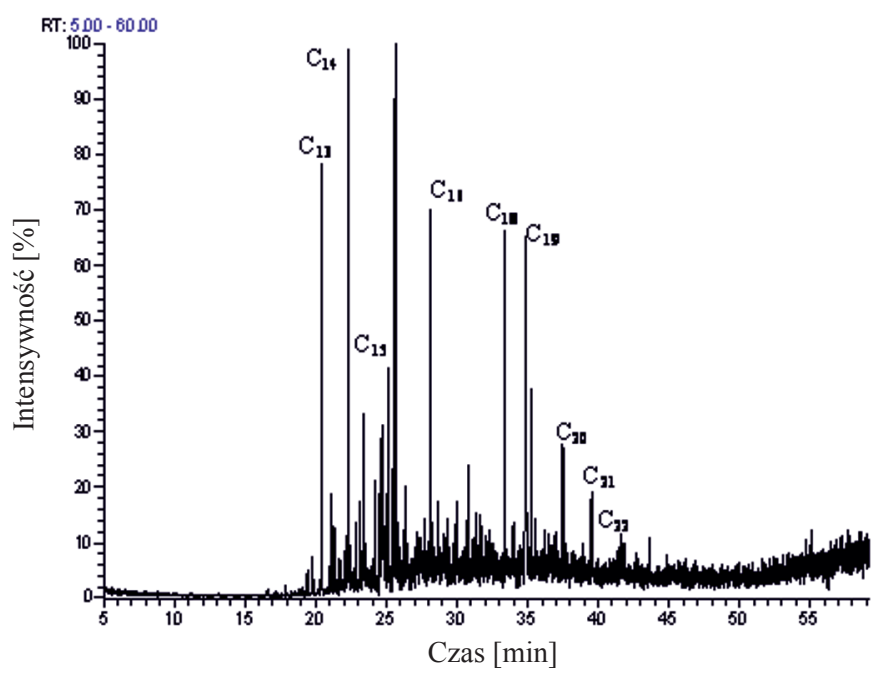

Rys. 5. Skład arylowych izoprenoidów w próbce M-5: trimetyloarylowe izoprenoidy $(\mathrm{m} / \mathrm{z}=133,134)$ 
W próbce M-8 (stropowa część serii rogowcowej dolnej, bezpośrednio poniżej margli podcergowskich) wartość wskaźnika Pr/Ph wynosi 1,29 i świadczy o niskotlenowym środowisku sedymentacji, co potwierdza skład homohopanów (malejący szereg od $\mathrm{C}_{30}$ do $\mathrm{C}_{35}$ ). W próbce tej stwierdza się małą koncentrację oleananu oraz wyższą steranów $\mathrm{C}_{29}$, co raczej wskazuje na większy udział związków pochodzenia lądowego. Wskaźniki oparte na izoprenoidach łańcuchowych i arylowych wskazują na długotrwałą fotyczną strefę anoksyczną.

Podsumowując, stwierdzono, że środowisko sedymentacji menilitów oligoceńskich było brakiczne (udział wód słodkich i słonych), o charakterze deltowym, a zawarty w nich kerogen jest pochodzenia głównie lądowego [17].

Według literatury [11] na rysunku 6 znajdują się trzy różne strefy, różniące się poziomem wód morskich w basenie i typem osadu. W pierwszym obszarze ulokowane są próbki reprezentujące materię deponowaną w warunkach tlenowych w przejściowej strefie głębokości kolumny wody morza. Drugi obszar reprezentuje materię organiczną, której depozycja odbywała się podczas występowania wysokiego stanu wód morskich przy maksimum zalewu. Obszar trzeci (znajduje się w górnym prawym rogu diagramu) gromadzi próbki mieszane, deponowane w aerobowych warunkach przy niskim poziomie wód morskich i intensywnym natlenieniu wód szelfowych. Opierając się jedynie na wynikach zamieszczonych na diagramie (rysunek 6), można wywnioskować, że większość badanych próbek wykazuje pochodzenie materii organicznej deponowanej w środowisku o trwałej fotycznej strefie anoksycznej. Natomiast biorąc pod uwagę brak izorenieratanu w próbkach, należałoby stwierdzić, że fotyczna strefa anoksyczna występowała w kolumnie wody, lecz krótkotrwale. Należy mieć na uwadze ostrożność w formułowaniu definitywnych wniosków na podstawie diagramu (rysunek 6) i konfrontować je $\mathrm{z}$ wnioskami płynącymi z obecności i składu molekularnego biomarkerów oraz z przesłanek sedymentologicznych.

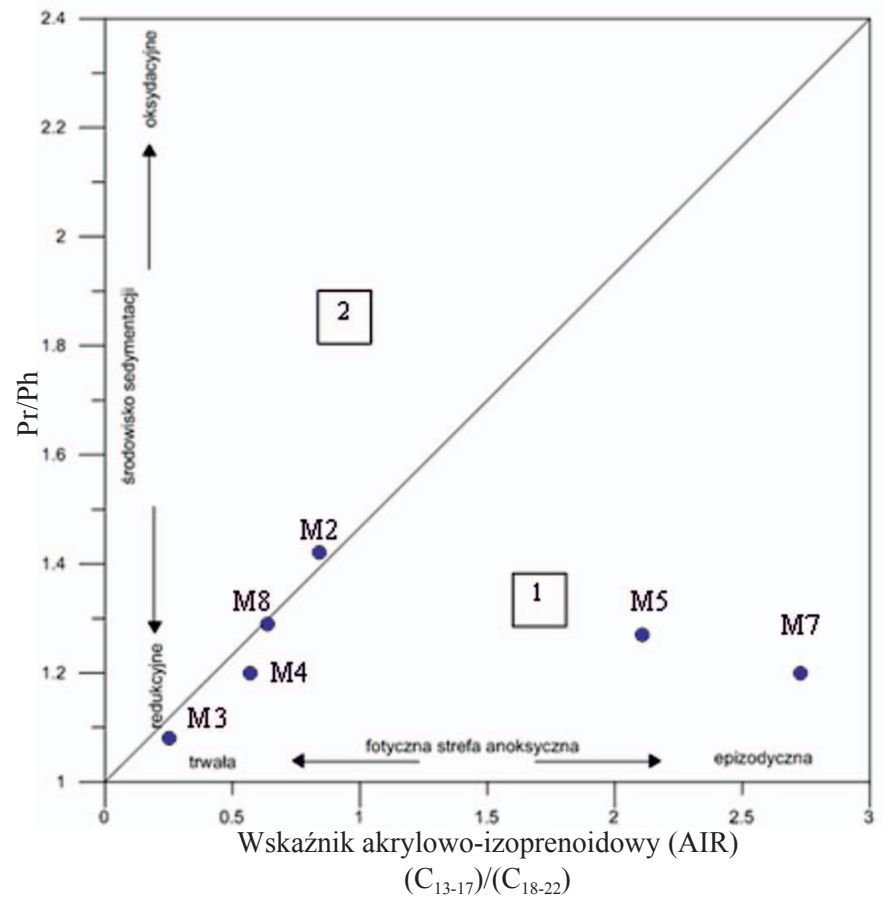

Rys. 6. Diagram pokazujący zależność pomiędzy wskaźnikami AIR i Pr/Ph

\section{Podsumowanie}

1. Opracowano i wdrożono metodykę identyfikacji arylowych izoprenoidów znajdujących się we frakcji aromatycznej ekstraktów ze skał macierzystych.

2. W próbkach reprezentujących różne wydzielenia litostratygraficzne stwierdzono i/lub zidentyfikowano arylowe izoprenoidy (trimetyloarylowe, dimetyloarylowe oraz diarylowe). W próbkach z dolomitu głównego arylowe izoprenoidy nie mogły być wykorzystane w korelacji ze wskaźnikiem $\mathrm{Pr} / \mathrm{Ph} \mathrm{z}$ uwagi na redukcyjne warunki środowiska sedymentacji $(\mathrm{Pr} / \mathrm{Ph}<<1,0)$. Wartości wskaźnika $\mathrm{Pr} / \mathrm{Ph}$ znajdują się poza zakresem stosowalności diagramu (rysunek 6). Próbki te zapewne pochodzą z głębszego poziomu basenu sedymentacyjnego.

3. Większość badanych próbek w składzie arylowych izoprenoidów charakteryzowała się obecnością homologów w wąskim zakresie liczby atomów węgla w cząsteczce.

4. Z powodu wskazanego we wniosku powyżej spośród 50 badanych próbek jedynie 12 spełniało warunki, dzięki którym można było określić wskaźnik AIR oparty na ary- lowych izoprenoidach, a próbki reprezentujące utwory oligoceńskie wykorzystano do korelacji według diagramu (rysunek 6), dzięki któremu można określić typ anoksycznej strefy fotycznej.

5. Stwierdzono, że środowisko sedymentacji menilitów oligoceńskich było brakiczne (udział wód słodkich i słonych), o charakterze deltowym z fotyczną strefą anoksyczną. Nie ustalono jednoznacznie, czy fotyczna strefa anoksyczna miała charakter długotrwały, czy krótkotrwały, chociaż większość próbek lokowała się na diagramie w obszarze długotrwałej strefy fotycznej.

6. Substancja organiczna występująca w przebadanych menilitach jest pochodzenia głównie lądowego, a jej depozycji towarzyszyły procesy degradacji, także bakteryjnej.

7. Interpretację natury paleośrodowiska depozycji wynikającą z analizy arylowych izoprenoidów należy potwierdzać wnioskami opartymi na obecności innych grup biomarkerów oraz wskazaniami badań sedymentologicznych. 
Prosimy cytować jako: Nafta-Gaz 2017, nr 11, s. 857-863, DOI: 10.18668/NG.2017.11.05

Artykuł nadesłano do Redakcji 31.01.2017 r. Zatwierdzono do druku 1.08.2017 r.

Artykuł powstał na podstawie pracy statutowej pt.: Wykorzystanie składu związków arylo izoprenoidowych do wyznaczania granic stref atoksycznych - praca INiG - PIB na zlecenie MNiSW; numer zlecenia: 09/SG/2016, numer archiwalny: DK-4100-09/15.

\section{Literatura}

[1] Brocks J.J., Love G.D., Summons R.E., Knoll A.H., Logan G.A., Bowden S.A.: Biomarker evidence for green and purple sulphur bacteria in a stratified Paleoproterozoic sea. Nature 2005, vol. 437, s. 866-870.

[2] Brocks J.J., Schaeffer P.: Okenane, a biomarker for purple sulfurbacteria (Chromatiaceae), and other new carotenoid derivatives from the 1640 Ma Barney Creek Formation. Geochim. Cosmochim. Acta 2008, vol. 72, nr 5, s. 1396-1414.

[3] El-Shafeiy M., Birgel D., El-Kammar A., El-Barkooky A., Wagreich M., Mohamed O., Peckmann J.: Palaeoecological and post depositional changes recorded in Campanian-Maastrichtian black shales, Abu Tartur plateau, Egypt. Cretaceous Research. 2014, vol. 50, s. 38-51.

[4] Frimmel A., Oschmann W., Schwark L.: Chemostratigraphy of the Posidonia Black Shale, SW Germany: I. Influence of sea-level variation on organic facies evolution. Chemical Geology 2004, vol. 206, nr 3-4, s. 199-230.

[5] Grice K., Cao C., Love G.D., Bottcher M.E., Twitchett R.J., Grosjean E., Summons R.E., Turgeon S.C., Dunning W., Jin Y.: Photic zone euxinia during the Permian-Triassic superanoxic event. Science 2005, vol. 307, s. 706-709.

[6] Hong L., Shen C., Zhang Z., Liu M., Sheng G., Peng P., Hsu C.S.: 2,3,6-/2,3,4-Aryl Isoprenoids in Paleocene Crude Oils from Chinese Jianghan Basin: Constrained by Water Column Stratification. Energy Fuels 2015, vol. 29, nr 8, s. $4690-4700$.

[7] Hu S., Wilkes H., Horsfield B., Chen H., Li S.: On the origin, mixing and alteration of crude oils in the Tarim Basin. Org. Geochem. 2016, vol. 97, s. 17-34.

[8] Matyasik I., Bieleń W.: Oznaczanie jakościowe i ilościowe (za pomoca pułapki jonowej Polaris Q) zwiazków chemicznych: oleananu i bisnorhopanu, stosowanych $w$ interpretacji geochemicznej. Nafta-Gaz 2013, nr 5, s. 361-367.

[9] Peng P.A., Sheng G.Y., Jiang J.G., Fu J.M., Bao J.P., Yu Z.Q.: Hydrocarbon compositions of soluble organic matter and characteristics of biomarkers in source rocks in a hypersaline lacustrine basin. In Generation, Migration and Accumulation of Oils and Gases in Hypersaline Lacustrine Basin, China. Guangdong Science and Technology Press: Guangzhou, China 2004, vol. 6, s. 139-188.

[10] Santos A.L., Sousa E., Santos Júnior G.R., Rocha M., Lopes J.A.D., Citó A.M.G.L., Reis F.A.M., Souza I.V.A.F, de Lima S.G.: Identification of aryl isoprenoids in oils from

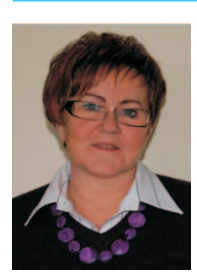

Prof. nzw. dr hab. inż. Irena MATYASIK

Adiunkt, kierownik Laboratorium Nafty i Gazu

w Zakładzie Geologii i Geochemii.

Instytut Nafty i Gazu - Państwowy Instytut Badawczy

ul. Lubicz 25 A

31-503 Kraków

E-mail: irena.matyasik@inig.pl
Sergipe-Alagoas Basin, northeastern Brazil using Triple Quadrupole GC-MS/MS. Latin American Congress on Organic Geochemistry 2014.

[11] Schwark L., Frimmel A.: Chemostratigraphy of the Posidonia black shale, SW Germany: II. Assessment of extent and persistence of photic-zone anoxia using aryl isoprenoid distributions. Chem. Geol. 2004, vol. 206, nr 3-4, s. 231-248.

[12] Sousa Júnior G.R., Santos A.L.S., de Lima S.G., Lopes J.A.D., Reis F.A.M., Santos Neto E.V., Chang H.K.: Evidence for euphotic zone anoxia during the deposition of Aptian source rocks based on aryl isoprenoids in petroleum, Sergipe-Alagoas Basin, northeastern Brazil. Org. Geochem. 2013, vol. 63, s. 94-104.

[13] Summons R.E., Powell T.G.: Identification of aryl isoprenoids in source rocks and crude oils: Biological markers for the green sulphur bacteria. Geochim. Cosmochim. Acta 1987, vol. 51, nr 3, s. 557-566.

[14] Sun Y.G., Xu S.P., Lu H., Chai P.X.: Source facies of the Paleozoic petroleum systems in the Tabei uplift, Tarim Basin, NW China: implications from aryl isoprenoids in crude oils. Org. Geochem. 2003, vol. 34, nr 4, s. 629-634.

[15] Wang L., Song Z.G., Yin Q., George S.C.: Paleosalinity significance of occurrence and distribution of methyltrimethyltridecyl chromans in the Upper Cretaceous Nenjiang Formation, Songliao Basin, China. Org. Geochem. 2011, vol. 42, nr 11, s. 1411-1419.

[16] Zhang C., Zhang Y., Cai C.: Aromatic isoprenoids from the 25-65 Ma saline lacustrine formations in the western Qaidam Basin, NW China. Org. Geochem. 2011, vol. 42, nr 7, s. $851-855$.

[17] Ziemianin K., Brzuszek P., Słoczyński T., Jankowski L.: Dispersed organic matter in shales from Menilite Beds within Polish Outer Carpathians - preliminary diagnosis. Nafta-Gaz 2015, nr 9, s. 615-623.

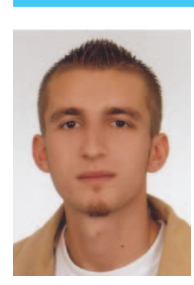

Mgr inż. Wojciech BIELEŃ

Starszy specjalista badawczo-techniczny w Zakładzie Geologii i Geochemii.

Instytut Nafty i Gazu - Państwowy Instytut Badawczy ul. Lubicz $25 \mathrm{~A}$

31-503 Kraków

E-mail:wojciech.bielen@inig.pl

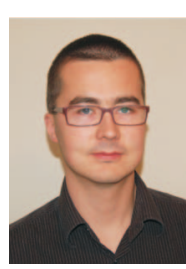

Mgr inż. Marek JANIGA

Asystent w Zakładzie Geologii i Geochemii. Instytut Nafty i Gazu - Państwowy Instytut Badawczy ul. Lubicz 25 A

31-503 Kraków

E-mail: marek.janiga@inig.pl 